\title{
XI. A reply to Mr. John Murray, “on the Apparatus for restoring the Action of the Lungs in apparent Death"
}

Mr. John Moore Jun.

To cite this article: Mr. John Moore Jun. (1822) XI. A reply to Mr. John Murray, "on the Apparatus for restoring the Action of the Lungs in apparent Death" , Philosophical Magazine Series 1, 60:291, 62-64, DOI: 10.1080/14786442208652789

To link to this article: http://dx.doi.org/10.1080/14786442208652789

曲 Published online: 29 Jul 2009.

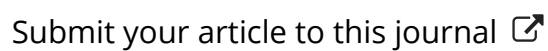

Џll Article views: 2

Q View related articles $\sqsubset$ 
minated the arrangement. The patches of tinfoil, and of course the ends of the wires which terminated below and above them, were separated from each other about two inches. When the electric discharge was made by placing one of the balls of the insulated discharging rod in contact with the further end of the upper wire, \&c. the under patch of tinfoil exhibited an indent upward; and the upper patch an indent downward: they were frequently perforated, and the burs similarly directed. If I used two wires below, parallel to each other, say $\frac{3}{4}$ ths inch apart, and one wire above, then had I two indents or two burs directed upwards, and one indent or one bur downwards; and on the other hand, when I employed two raves above and one below, the phanomena were reversed, there being two burs or indents from above, and one only from below.

In this detail there is described another phanomenon not less interesting. I coated uniformly with China ink the ball of the rod connected with the internal metallic surface of the Leyden jar, as well as that of one of the balls of the jointed discharger, and placed a vertical card between these balls. When I made the discharge, the card exhibited the usual appearance of a bur raised on both sides. But independently of this, I found a circular portion of the China ink displaced firom both of these balls, and an indent in each of them. Each ball was an inch distant from the respective surfaces of the interposed card, and the discharge was a powerful one. It was on these that I founded the opinion that Mons. Moll's experiment was only a modification of mine; and I have transmitted to Professor Moll of Utrecht a note of these experiments, agreeably to his request to me.

It is highly satisfactory for me to receive, after the lapse of a few years, the verification of these experiments, sealed as it were by the signet of celestial fire.

I have the honour to be, sir,

Your obliged and humble servant,

May 15, 1822. J. Murray.

XI. A Reply to Mr. John Murnay, "on the Apparalus for restoring the Action of the Lungs in apparent Death." By Mr. JoHn Moore, Jun.

\section{To Dr. Tilloch.}

Sir, - Is it not singular that Mr. Murray should have been so displeased with me, for the notice I took of his machine for producing artificial respiration, when he has given an invitation to the public to completely investigate it; requesting them 
to show objections, if any were to be found? He says, "I confess that I am not a little surprised at a communication by Mr. John Moore junior, in your Number for March last: with sufficient self-complacency this correspondent considers the plan he proposes for restoring the action of the lungs as more complete than my invention." I would ask Mr. J. Murray what was the reason he stopped at his invention; was it because, by not publishing the reason I gave for my conclusions, he thought to gain a trifling advantage? He writes, I consider my plan the best, "with sufficient self-complacency:" ought he to be angry because $I$ felt a pleasure in what $I$ then was writing, when the same feelings, I have no doubt, induced him to publish his invention?

Mr. Murray says that "Mr. John Moore junior is pleased to adopt the form of the syringe which I had done long before; aye, and constructed and published too." I deny having adopted the form of Mr. Murray's syringe; for my plan was shown to some of my friends some years ago: but my first letter to one of them in London, relating to the apparatus, is dated February 1819. His favour to me in reply, 9th October 1819, which is about two years before I saw Mr. Murray's description.

Mr. Murray writes, "I never believed myself infallible, or that my invention was incapable of improvement. I hope I am not so absurd or unreasonable : but I do fearlessly assert, that his improvement, as he insinuates it to be, is one which adds to the complexity of the mechanism without subserving its utility; nay, rather injures the cause it is meant to serve."

What proof is there in a "fearless assertion?" Why did he not give unequivocal proof that it was incompetent to perform that which I had stated it would? This would have been much better than a "fearless assertion." How can he conclude that I "insinuated ?" I said that I considered my plan more complete than his, stating my reason for the conclusion; but if I had been a dealer in positive assertions, I should have said mine was superior to his.

Mr. Murray says, "Various plans presented themselves to my mind before I completed my improved apparatus: a structure somerohat similar to the one now set forth and vaunted by your correspondent John Moore junior, was immediately rejected from its complete uselessness." This proves nothing, as he has only asserted it was somerohat similar; nor does he tell $u$ in what particular it was dissimilar. Was it not in some essential part? or will he 'fearlessly assert' that mine is completely useless? 
If Mr. Murray had left out the word "vaunted," it would have been understood as well, and quite as correct.

Mr. Murray says that his machine was 'immediately rejected,' because, until natural respiration returns, the air undergoes no change whatever. If it be as Mr. Murray has stated, that the air undergoes no change whatever, how is it that the individual becomes reanimated? He says it is absurd to give a continued supply of fresh air to an individual, until the natural respiration returns. Will Mr. Murray say that the natural respiration returns fully and at once? because, if it returns by degrees, will not the air be decomposed in proportion to returning life? And as the air becomes charged with carbon as the person continues reanimating, does it not follow that it should be withdrawn, and fresh supplied in its place, unless Mr. Murray can show that fresh air would injure or prevent resuscitation; or that the 'victim' it would keep in ' inglorious repose?"

Mr. Murray states, "As to the application of the instrument to the purposes of a gas blow-pipe, and the exhibitions of nitrous oxide, I can have no ambition to claim an interest in sueh an association; the transition from the resuscitation of human beings to a gas blow-pipe, \&c. is so entirely ludicrous, that $I$ am astonished such an erratic fancy should be indulged in." Here he has wrong stated my expressions; but even suppose they were as he has stated them, would any man in his senses think of ridiculing the mentioning in immediate succession the several uses of a machine? Perhaps Mr. Murray was indulging in an ' erratic fancy,' or would he not have observed, that I was describing some mechanism, not the resuscitation of human beings as he has asserted?

'The remainder of his motley communication does not relate to me, although he has headed it "On the apparatus for restoring the action of the lungs in apparent death."

But the charge, that I endeavoured to detract from the merits of his invention, requires for answer, that I have not so done; I said that I considered my plan more complete than his, and gave my reasons for it.

In conclusion, I shall merely say, that should Mr. Murray describe an instrument more complete than mine, I shall not be angry with him for it; for I consider the advancement of humanity and science far superior to individual feeling.

Lawrence Hill, June 80, 1829.

I remain, sir, respectfully yours, \&c. JoHn Moone Junior. 